\section{The sources}

1-Чубарова Т.В. Экономика здравоохранения: теоретические аспекты. М., Институт Экономики РАН, 2008, или на сайте www.inecon.ru.

2-Реформа управления и финансирования здравоохранения. И. М. Шейман. Москва. «Русь». Издатцентр, 2005.
3-Доклад о состоянии здравоохранения в мире(ВО3) 2010 г.128стр.

4- World social security report 2010/11: providing coverage in the time of crisis and beyond. Geneva, International Labour Organization, 2010.

\title{
STRUCTURE OF THE LABIAL SALIVARY GLANDS AT THE AGE OF 11-20 YEARS
}

DOI: $10.31618 /$ ESU.2413-9335.2019.3.62.103

Shadlinski $V . B$.

Azerbaijan Medical University, Department of Human anatomy, head of department, member of RAMS, doctor in medicine, professor

Abdullayev A.S.

Azerbaijan Medical University,

Department of Human anatomy, associate professor, PhD in Medicine

\begin{abstract}
.
For microscopic examination, preparations of the upper and lower lips at the age of 11-20 years were used. The number of small salivary glands in the upper lip is 92.0, varying in the range from 78 to 107 . The number of lower labial glands in this age group is 103.5 as an average and, has minimum and maximum values of 84 and 126 , respectively. The numerous peripheral sensory nerve endings found in the terminal sections and in the ducts of the glands are represented by polymorphic structures. The most common are encapsulated endings resemble the end-bulbs of Krause. Our study showed that the labial glands are located on the upper and lower lips in places of the greatest accumulation of nerve and vascular elements, which apparently is due to their influence on the secretion process.

Key words: oral mucosa, upper and lower lips, labial glands, lobes, serous demilunes or crescents of Gianuzzi, intercalated ducts, end-bulbs of Krause, striated ducts.

The normal functioning of the oral mucosa in adolescence and youth is closely related to the growth and development of the salivary glands. Literary data directly indicate that most of the pathological processes in the oral mucosa is caused by a decrease or even loss of the protective and barrier function of saliva [1, p.453-464; 2, p.111-127]. According to modern concepts, most of the pathological conditions of the lips, which later have malignant transformations, are associated with a decrease in the secretory activity of the labial salivary glands $[3$, c.122-128; 4 , c.28-31; 5, p.370$373 ; 6$, p.275-280; 7, p.382-387]. By the frequency of tumor lesions of all glands of the oral cavity, the labial glands rank second after the parotid gland $[8, \mathrm{p} .128$ 132; 9, p.200-207]. Along with this, it is indicated that the tumors of these glands tend to metastasize $[10, p$. 620-622].

An important practical problem is also the fact that a number of common systemic diseases of the human body have as the first symptom changes in the structure of the labial glands, which indicates a high diagnostic value of knowledge about their structure [11, p.18-20; 12, p.171-180; 13, p.879-885; 14, p. 875-883]. Unfortunately, the question of the structural features of the small salivary glands of the lips of adolescents and youths is still poorly covered; a period in which the body is reorganized hormonally, and the mucous membrane of the lips is particularly sensitive due to changes in the neuro-humoral status to various pathogens [15, p.9-64].

The aim of the investigation was to study the structural features of the labial salivary glands at the age of 11-20 years.

Material and methods of the investigation. For microscopic examination, preparations of the upper and lower lips at the age of 11-20 years were used. A total of 4 cases were investigated. Preparations for the study were taken respectively from the medial and lateral sections of both lips. Taking into account the specifics of the forthcoming study, the pieces intended for light-optical study were fixed in a $10 \%$ solution of acid formalin, dehydrated in alcohols of ascending concentration and housed into paraffin. Microtome sections with a thickness of $5 \mu \mathrm{m}$ were stained both with trivial histological (hematoxylin-eosin, van Gieson's stain, thionin) and selective histochemical methods (PAS-reaction). To study the nervous structures of the salivary glands, silver impregnation method according to Rasskazova was used. The arithmetic data obtained was subjected to statistical processing by methods of variation statistics. The nonparametric Wilcoxon U-test (Mann-Whitney) was used.

The results of investigation and their discussion. At the age of 11 to 20, small salivary glands are found almost throughout the upper portion of the oral vestibule, symmetrically located on both sides of the frenulum of upper lip. In the lower regions they are located mainly in the lower lip, where they make up a glandular plate, up to $5 \mathrm{~cm}$ long and $1-1.5 \mathrm{~cm}$ wide, which without noticeable borders passes at the level of the angles of mouth into the group of glands of the anterior cheek areas. The glands of the lower and upper parts of the lips are mainly located along the nerves and vessels.

The number of small salivary glands in the upper lip is 92.0, varying in the range from 78 to 107 . Wherein 48.25 (45-52) glands are in the middle of the upper lip, and 43.75 (33-55) glands in the lateral areas.
\end{abstract}


The area occupied by the small salivary glands of the upper lip in this age period is $0.577 \mathrm{~cm}^{2}$. The difference in the area of the upper labial glands with the previous age group (6-10 years) is statistically significant with a probability level of $p<0.05$. The largest glands are located in the lateral part of the upper lip and the area occupied by them is $0.591 \mathrm{~cm}^{2}\left(0.588-0.595 \mathrm{~cm}^{2}\right)$. These glands are statistically more glands located in the middle of the upper lip ( $\mathrm{p}<0.05)$.

The number of lower labial glands in this age group is 103.5 as an average and, has minimum and maximum values of 84 and 126, respectively. Differences in numbers with the upper labial glands and the previous age period do not have a significant value. The lower labial glands have an area of $0.480 \mathrm{~cm}^{2}$. They are statistically smaller in the small glands of the upper lip $(\mathrm{p}<0.05)$.

Table of ratios of the number and area of the salivary glands of the upper and lower lips at 11-20 ages.

\begin{tabular}{|c|c|c|c|c|}
\hline \multirow{2}{*}{\multicolumn{2}{|c|}{$\begin{array}{l}\text { The salivary glands } \\
(\mathrm{n}=4)\end{array}$}} & \multicolumn{2}{|c|}{ The parts of lips } & \multirow[t]{2}{*}{ Total } \\
\hline & & Medial & Lateral & \\
\hline \multirow{7}{*}{ Number of glands } & $\begin{array}{l}\text { Upper } \\
\text { lip }\end{array}$ & $\begin{array}{l}48.25 \\
(45-52)\end{array}$ & $\begin{array}{c}43.75 \\
(33-55)\end{array}$ & $\begin{array}{c}92.0 \\
(78-107)\end{array}$ \\
\hline & $\mathrm{p} 1$ & & $\begin{array}{l}\text { Statistically not signif- } \\
\text { icant }\end{array}$ & \\
\hline & p3 & $\begin{array}{c}\text { Statistically not signif- } \\
\text { icant }\end{array}$ & $<0.05$ & $\begin{array}{c}\text { Statistically not signif- } \\
\text { icant }\end{array}$ \\
\hline & $\begin{array}{l}\text { Lower } \\
\text { lip }\end{array}$ & $\begin{array}{c}44.0 \\
(41-46)\end{array}$ & $\begin{array}{c}59.5 \\
(43-80)\end{array}$ & $\begin{array}{c}103.5 \\
(84-126)\end{array}$ \\
\hline & $\mathrm{p} 1$ & & $\begin{array}{l}\text { Statistically not signif- } \\
\text { icant }\end{array}$ & \\
\hline & $\mathrm{P} 2$ & $\begin{array}{c}\text { Statistically not signif- } \\
\text { icant }\end{array}$ & $\begin{array}{l}\text { Statistically not signif- } \\
\text { icant }\end{array}$ & $\begin{array}{c}\text { Statistically not signif- } \\
\text { icant }\end{array}$ \\
\hline & p3 & $\begin{array}{c}\text { Statistically not signif- } \\
\text { icant }\end{array}$ & $\begin{array}{c}\text { Statistically not signif- } \\
\text { icant }\end{array}$ & $\begin{array}{c}\text { Statistically not signif- } \\
\text { icant }\end{array}$ \\
\hline \multirow{7}{*}{$\begin{array}{l}\text { Area (square centi- } \\
\text { meter) }\end{array}$} & $\begin{array}{l}\text { Upper } \\
\text { lip }\end{array}$ & $\begin{array}{c}0.564 \\
(0.5545-0.5715) \\
\end{array}$ & $\begin{array}{c}0.591 \\
(0.5882-0.5951) \\
\end{array}$ & $\begin{array}{c}0.577 \\
(0.5688-0.5816) \\
\end{array}$ \\
\hline & $\mathrm{p} 1$ & & $<0.05$ & \\
\hline & p3 & $<0.05$ & $<0.05$ & $<0.05$ \\
\hline & $\begin{array}{c}\text { Lower } \\
\text { lip }\end{array}$ & $\begin{array}{c}0.474 \\
(0.4616-0.4837) \\
\end{array}$ & $\begin{array}{c}0.486 \\
(0.4819-0.4922) \\
\end{array}$ & $\begin{array}{c}0.480 \\
(0.4737-0.484) \\
\end{array}$ \\
\hline & $\mathrm{p} 1$ & & $\begin{array}{c}\text { Statistically not signif- } \\
\text { icant }\end{array}$ & \\
\hline & $\mathrm{P} 2$ & $<0.05$ & $<0.05$ & $<0.05$ \\
\hline & p3 & $<0.05$ & $<0.05$ & $<0.05$ \\
\hline
\end{tabular}

Note: $p$ - the statistical significance of the differences in the corresponding indices of the salivary glands of the lip according to the Wilcoxon criterion (Mann-Whitney) : p1 - the middle and angle of the lip; p2 - upper and lower lips. p3 - 6-10 (previous period) and 11-20 years.

The common ducts of these glands are relatively long; near the acinar parts, they are sometimes somewhat curved and narrowed, and in their middle part they are dilated. In some places in the region of the lower lips, there are glands consisting of 2-3 rather large lobes closely adjacent to one another, located mainly in the initial sections of the excretory duct, some of them often have lateral branches along which the lobules are smaller. Along with the explained above glands in the lower lip there are single bunchy glands, with more branched ducts. Their lateral branches depart from the main duct along its entire length, mostly at right angles. The terminal sections of such glands consist of a rather large number, from 15 to 20 and more small lobules with narrow ducts, which narrowed or dilated near their openings. The small salivary glands of the lips near the angles of mouth are of two types. Some of them have a spherical shape with a clearly expressed large lobulation. The common excretory ducts of such glands in the middle part have a cigar-shaped expansion, and along their extension, lateral branches with acinar sections at their free ends are located. Glands of another type have a more complex, branched form. Their ducts are considerably narrower than the ducts of the first group of glands and, with a double or triple dichotomous branching, end in extremely small lobules constituting the lobes. These glands in their appearance resemble a bunch of grapes. 
Microscopic examination of the small salivary glands of the lips are complex tubular-alveolar, in their structural features, they are mostly serous glands. The proper membrane of the terminal sections of these glands is well defined. The connective tissue of the mucous membrane forms papillae of microscopic size. Outwards from the mucous membrane near the angles of mouth, between the bundles of muscles, there are also complex tubular-alveolar glands of the mixed type, with a predominance of serous, sometimes mucosal terminal sections, with pronounced serous demilunes or crescents of Gianuzzi. Mucocytes lie in the central part of the mixed terminal section. The demilunes formed by seromucous cells is better expressed in them than in other age groups. Serous cells forming the demilunes differ significantly from the corresponding cells in other age groups. These cells secrete both serous and mucosal secretions. Their secretory granules respond to mucin. Myoepithelial elements form the outer layer in all types of the terminal sections.

The intercalated ducts of the small salivary glands are short narrow tubules, starting directly from their terminal secretory sections. They are usually very branched. Insertion ducts lined by cubic or flat epithelium. The second layer in them is formed by myoepitheliocytes. The striated salivary ducts are the continuation of the intercalated ducts and are also located inside the lobules. Their diameter is much larger of the same parameter of intercalated ducts, the lumen is well defined. The striated ducts branch and often form ampular extensions. They are lined with a single layer of cylindrical epithelium. The cytoplasm of their cells is acidophilic. The common excretory duct of the glands is lined with a multi-layered highly prismatic epithelium and opens to the surface of the mucous membrane.

The numerous peripheral sensory nerve endings found in the terminal sections and in the ducts of the glands are represented by polymorphic structures. The most common are encapsulated endings resemble the end-bulbs of Krause. They are formed by the myelinated nerve fiber of a large or medium caliber, the end branching of which has the appearance of a complex glomerulus. It should be noted that encapsulated receptors like end-bulbs of Krause are located by 6-10 bodies, forming the dense receptor fields in the walls of the ducts of the salivary glands. Some encapsulated endings are surrounded by blood vessels on all sides. By the end of this age period, the observed changes in the small glands of the lips consist not only in increasing the length of the area they occupy, but also in the presence of glands, as well as in lengthening the ducts and increasing the size of the glands. The glands of the anterior regions of the oral vestibule are located in the submucosal layer of the lips, make up like glandular plates that prominent into the cheek area at the level of the angles of mouth. The lower labial glandular plate, prominent beyond the angles of mouth, reaches a length of $8 \mathrm{~cm}$ and a width of 1 to $2 \mathrm{~cm}$. The widest part of this glandular plate corresponds to the central part of the lower lip, the narrower one is located at the level of the angles of mouth, and near the frenulum of the upper lip it is narrowed. The glands of the lips are located like 35 rows that not strictly parallel and unequal in length, with the shortest row of glands lying at the transitional fold, the longer one closer to the edge of the lips. A number of glands of the upper lip without noticeable borders passes into the cheek area. In the region of the upper lip, the glands predominate, usually consisting of one rather large or, more rarely, several (3-4) smaller lobes centrally located in the initial part of the main excretory duct, and extending along the lateral branches.

The common excretory duct of their mostly direct, sometimes at the place of its lateral branches and at the openings has an extension. In the area of the lower lip, along with such forms of glands, glands are also found with narrower excretory ducts, branched mainly along the magistral type. Their acinar departments consist of 5-8 lobes of various sizes, round or oval, located on the side branches of their main duct. In the area near the angles of mouth, the small salivary glands in their form resemble a bunch of grapes, their main divisions consist of a large number (10-15) of isolated lobes, which in turn consist of even smaller lobules. Their excretory ducts are relatively narrow, long and usually have a magistral type of branching. The bodies of glands near the angles of mouth, for the most part lie in the submucosal layer and between the bundles of the buccinator muscle. The lamina propria of the mucous membrane, consisting of loose fibrous connective tissue, forms high narrow papillae that prominent deep into the epithelium. Behind it is a strongly developed layer of elastic fibers. Muscular plate mucous membrane is missing. The submucous layer formed by loose unformed fibrous connective tissue, rich in fat and lymphoid elements and mucous-serous small salivary glands. The glands are complex tubular-alveolar, with a predominance of serous components. The serosocytes are located on the basement membrane; the nuclei are localized closer to the basal pole. The mucocytes are with characteristic serous demilunes or crescents of Gianuzzi, in the cytoplasm of which the secret is not determined. Terminal sections of the glands are surrounded by dark myoepithelium cells. The excretory ducts of the small salivary glands are divided into intercalated, striated and common excretory duct. Intercalated ducts are less branched and shorter than other ducts. The striated ducts are very well developed; they are long and strongly branched. There are often narrowings and balloon-like extensions in them. The cylindrical epithelium lining them shows well-impressed basal striation. The lumens of glands are mostly narrow; each cell is surrounded by fusiform myoepithelium cells. The common excretory ducts are lined with one or two-layer cylindrical epithelium, passing into the multilayered epithelium. The main excretory duct of the minor salivary gland is branched intensively. Also are found myelin and non-myelin nerves, following along the vessels and ducts. They form the nerve endings in the walls of blood vessels, on the terminal sections and in the excretory ducts of the glands. Nerve endings are encapsulated end-bulbs of Krause type and, receptors of the type of compact glomeruli, which are mainly embedded in the terminal sections of the glands of the lower lips. They were also detected in the walls of the ducts of the small salivary glands. Moreover, unlike encapsulated 
endings, receptors of the type of compact glomeruli are located in the subepithelial layer.

Thus, the salivary glands play an important role in the functioning of the mucous membrane of the upper and lower lips, in all metabolic reactions in them. Their number and area are important parameters that characterize the small salivary glands of the lips. The age period of 11-20 years is very important from this point of view; it is during this period that the processes of dynamic development take place. Our study showed that the labial glands are located on the upper and lower lips in places of the greatest accumulation of nerve and vascular elements, which apparently is due to their influence on the secretion process.

\section{References.}

1. Paszynska E, Slopien A, Slebioda ZS, Dyszkiewicz-Konwinska M, Weglarz M, Rajewski A. Macroscopic evaluation of the oral mucosa and analysis of salivary $\mathrm{Ph}$ in patients with anorexia nervosa. Psychiatr Pol., 2014, May-Jun; 48 (3): 453-464.

2. Hassona Y, Scully C. Salivary changes in oral mucosal diseases. Periodontol 2000., 2016, Feb; 70 (1):111-127.

3. Варшавский А.И, Губерская Т.А, Панченко К.И. Сравниетльная клинико-морфологическая характеристика регионарного кровообращения околоушных и губных слюнных желез при болезни Шегрена и хроническом паренхиматозном паротите. Терапевтический архив, 1992, т.64, №3, с.122128.

4. Гаубеншток Л.М, Леонтьев В.К. Количественно-топографическая характеристика малых слюнных желез губ. Стомалогия, 1990, №6, с.28-31.

5. de Sousa S.O, Sesso A, de Araujo N.S, de Aroujo V.C. Inverted ductal papilloma of minor salivary origin: morphological aspects and cytokeratin expression. European Archives of Oto-Rhino-Laryngology, 1995, vol.252, № 6, p. 370-373.

6. Guallact Domenech F, Molina Mira A, Gonzalez Martinez M.A, Pons Rocher F, Mompo
Romero L, Serrano Badio E. Adenomatoid hyperplasia of minor salivary glands. Anales Otorrinolaringologicos Iberoamericanos, 1994, vol.21, № 3, p.275-280.

7. Nico MM, Melo JN, Lourenco SV. Cheilitis glandularis: immunohistochemical expression of protein water channel (aquaporins) in minor labial salivary glands. J Eur Acad Dermatol Venereol., 2014, Mar; 28 (3): 382-387.

8. Kusama K, Iwanari S. Intraoral minor salivary gland tumors: a retrospective study of 129 cases. The Journal of Nihon University School of Dentistry, 1997, vol.34, №3, p.128-132.

9. Ogawa I, Nikai H, Takata T, Ijuhin N, Miyauchi M, Ito H, Vuhahula E. Clear cell tumors of minor salivary origin. An immunohistochemical and ultrastructural analysis. Oral Surgery, Oral Medicine, Oral Pathology., 1991, vol.72, №2, p.200-207.

10. Khan MN, Raza SS, Hussain Zaidi SA, Hag IV, Hussain AK, Nadeem MD, Farid K. Pleomorphic adenoma of minor salivary glands. J Ayub Med Coll Abbottabad., 2016, Jul-Sep; 28 (3): p.620-622.

11. Matsuda C. Salivary gland aplasia with cleft lip and palate. Oral Surgery, oral medicine, oral pathology, oral radiology and Endodontics., 1999, vol.87, №5, p.18-20.

12. Nair P.N, Schroeder H.E. Duct-associated lymphoid tissue (DALT) of minor salivary glands and mucosal immunity. Immunology., 1986, vol.57, № 2, p.171-180.

13. Lefarth FL, Prescher A, Angerstein W. Comparative ultrasonograpic and histomorphologic examination of lips. HNO, 2014, Dec; 62 (12): p.879-885.

14. Hiltz Lindenmüller I, Itin PH, Fistarol SK. Dermatology of the lips: inflammatory diseasesş Quintessence Int. 2014, Nov-Dec; 45 (10): 875-883.

15. Sonesson M. On minor salivary gland secretion in children, adolescents and adults. Swed Dent J Suppl., 2011; (215): 9-64.

\section{ОЖИРЕНИЕ: ЧТО МЫ СЕГОДНЯ ЗНАЕМ?}

DOI: $10.31618 / \mathrm{ESU} .2413-9335.2019 .3 .62 .102$

Жукова Лариса Алексеевна

Доктор мед.наук, профессор кафедры эндокринологии ФГБОУ ВО КГМУ Минздрава России, г.Курск

Андреева Наталья Станиславовна

Канд. мед наук, доиент кафедры эндокринологии ФГБОУ ВО КГМУ Минздрава России, г.Курск

Саенко Наталья Вячеславовна ассистент кафедры эндокринологии

АННОТАЦИЯ.

В представленном обзоре приведены и проанализированы основные механизмы формирования инсулинорезистентности по данным отечественных и зарубежных исследователей. Отмечена многофакторность патологических нарушений, в том числе роль кишечной микробиоты, связанных с развитием ожирения и возникающих при его развитии. Определены приоритетные направления обследования лиц с ожирением и возможные пути коррекции избыточной массы тела.

\section{ANNOTATION.}

In the presented review, the main mechanisms for the formation of insulin resistance are presented and analyzed according to the data of domestic and foreign researchers. The multifactorial nature of pathological disorders is noted, including the role of the intestinal microbiota associated with the development of obesity and arising 